\title{
Optimization of Machining Parameters for Product Quality and Productivity in Turning Process of Aluminum*
}

Optimización de los parámetros de mecanizado para la calidad del producto y productividad del proceso de torneado de aluminio

Received: November 8, 2019| Accepted: January 29, 2021 | Published on: November 2, 2021

\section{Sepideh Abolghasem ${ }^{\mathrm{a}}$}

Universidad de los Andes, Colombia

ORCID: 0000-0002-2079-4771

\section{Nicolás Mancilla-Cubides}

Universidad de los Andes, Colombia

ORCID: 0000-0002-4454-5286

* Research paper

${ }^{a}$ Corresponding author. E-mail: ag.sepideh10@uniandes.edu.co

DOI: https://doi.org/10.11144/Javeriana.iued26.ompp

How to cite this article:

S. Abolghasem and N. Mancilla-Cubides, "Optimization of machining parameters for product quality and productivity in turning process of aluminum" Ing. Univ. vol. 26, 2022. https://doi.org/10.11144/Javeriana.ived26.ompp 


\section{Abstract}

Modern production process is accompanied with new challenges in reducing the environmental impacts related to machining processes. The turning process is a manufacturing process widely used with numerous applications for creating engineering components. Accordingly, many studies have been conducted in order to optimize the machining parameters and facilitate the decision-making process. This work aims to optimize the quality of the machined products (surface finish) and the productivity rate of the turning manufacturing process. To do so, we use Aluminum as the material test to perform the turning process with cutting speed, feed rate, depth of cut, and nose radius of the cutting tool as our design factors. Product quality is quantified using surface roughness ( $\left.R \_a\right)$ and the productivity rate based on material removal rate (MRR). We develop a predictive and optimization model by coupling Artificial Neural Networks (ANN) and the Particle Swarm Optimization (PSO) multi-function optimization technique, as an alternative to predict the model response (R_a) first and then search for the optimal value of turning parameters to minimize the surface roughness ( $\left.R \_a\right)$ and maximize the material removal rate (MRR). The results obtained by the proposed models indicate good match between the predicted and experimental values proving that the proposed ANN model is capable to predict the surface roughness accurately. The optimization model PSO has provided a Pareto Front for the optimal solution determining the best machining parameters for minimum $R \_a$ and maximum MRR. The results from this study offer application in the real industry where the selection of optimal machining parameters helps to manage two conflicting objectives, which eventually facilitate the decision-making process of machined products

Keywords: Multi-Objective Optimization, Artificial Neural Networks, turning process, Surface Roughness.

\section{Resumen}

La producción moderna afronta desafíos en la reducción del impacto ambiental relacionado con los procesos de mecanizado y, particularmente, el proceso de torneado utilizado en la creación de componentes de ingeniería. Debido a esto, se han realizado numerosos estudios en el tema, buscando mejorar y facilitar el proceso de toma de decisiones. El objetivo del presente trabajo es optimizar la calidad de los productos mecanizados $\mathrm{y}$ el índice de productividad del proceso de torneado. Para esto, realizamos un estudio donde el Aluminio fue el material de prueba $\mathrm{y}$, la velocidad de corte, velocidad de avance, profundidad de corte y radio de punta de la herramienta fueron los factores de diseño. La calidad del producto fue medida mediante la rugosidad superficial (R_a) del material y la tasa de productividad según la tasa de remoción (MRR). Con dicha información desarrollamos un modelo predictivo y de optimización, mediante redes neuronales artificiales (ANN) y la técnica optimización multiobjetivo del Enjambre de partículas (PSO), para predecir la respuesta del modelo (R_a) primero y luego buscar el valor óptimo de los parámetros. Esto, buscando minimizar la R_a y maximizar la MRR. Los resultados obtenidos mostraron concordancia entre los valores predichos y experimentales, validando que el modelo de ANN es capaz de predecir la $\mathrm{R} \_a$ con precisión. Además, el modelo de optimización PSO ha proporcionado un Frente de Pareto para la solución óptima que determina los parámetros de mecanizado que generan un R_a mínimo y MRR máximo. Los resultados de este estudio ofrecen aplicación en la industria real, donde la selección de los parámetros de mecanizado óptimos contribuye con la gestión de los objetivos en conflicto, facilitando la toma de decisiones en los procesos de los productos mecanizados.

Palabras clave: Optimización MultiObjetivo, Redes Neuronales Artificiales, torneado, rugosidad superficial. 


\section{Introduction and Background}

Manufacturing is one of the main wealth-generating actions as it involves the conversion of materials into end products [1]. According to the studies relevant to the machine tools used in turning and milling processes, more than $99 \%$ of the environmental impacts related to these manufacturing processes are due to their usage of electrical energy [2]. The most important objectives for manufacturing companies are majorly centered on the costs, time, environmental impacts, and quality. Consequently, it is vital to efficiently select the machining parameters that lead to cost savings and environmental friendliness [3].

In this context, since manufacturing is a globalized and highly competitive industry, it is essential to increase productivity (reducing machining time) and, simultaneously, the quality of products. However, due to the characteristics of both the work and tools used, choosing the right parameter combination for the different properties of the materials used is a daily challenge. For this reason, a major challenge in metal cutting manufacturing processes is to minimize the manufacturing time and simultaneously maximize the quality or the enhanced material properties of the engineering components.

Surface Roughness $\left(R_{a}\right)$ and Material Removal Rate (MRR) are commonly used as adequate indicators for determining the quality of the surface finish in the final product and the production efficiency in machining processes, respectively. The Literature includes extensive researches on the selection of various objectives in machining aiming for the optimization of machining parameters to achieve the optimal outcomes. As shown in Table 1 , the objective functions selected in machining processes are mainly focused on the four central aims of cost, time, quality, and environmental impacts. Product quality is commonly taken into account by the surface roughness and the cutting tool wear, machining time (productivity rate) by material removal rate, environmental impacts by the cutting force and power consumption, and the cost of machining is fundamentally affected by all of the aforementioned objectives. It is notable that these objectives are often in conflict with one another. In order to accomplish these objectives, as listed in Table 1, various machining parameters are considered such as the cutting speed, the depth of cut, and the feed rate, among others. The reason why these three variables are included in most of the models is that they are proved to have a direct influence on the outcomes of the process such as the $R_{a}$, MRR, cutting force, energy, and power consumption. Additionally, the last column in Table 1 highlights the main contribution of the analysis on this topic. It is notable that in most of these studies, the approach includes two main stages: i) modelling in order to relate the parameters of machining to the objective functions, and ii) performing a multi-objective optimization technique that aims to obtain the range of optimal solutions. 
Table 1. Studies related to the optimization of machining process parameters with various objectives and parameters.

\begin{tabular}{|c|c|c|c|c|}
\hline & Article & Parameters used & Objective Function & Remarks \\
\hline [4] & $\begin{array}{l}\text { D'Mello, Pai and } \\
\text { Shetty, (2017) }\end{array}$ & $\begin{array}{l}\text { Cutting Speed, Feed Rate and Depth of } \\
\text { Cut }\end{array}$ & $\begin{array}{l}\text { Surface and Depth of } \\
\text { Roughness }\end{array}$ & $\begin{array}{l}\text { The Summation Wavelet - Extreme Learning Machine } \\
\text { (SW-ELM) technique yields very good results in terms } \\
\text { of prediction accuracy and runtime }\end{array}$ \\
\hline$[5]$ & $\begin{array}{c}\text { Kumar \& } \\
\text { Chauham, (2015) }\end{array}$ & $\begin{array}{l}\text { Cutting Speed, Approach Angle and } \\
\text { Depth of Cut }\end{array}$ & $\begin{array}{l}\text { Surface Roughness and } \\
\text { Cutting Force }\end{array}$ & $\begin{array}{l}\text { The roughness of the surface changes linearly with the } \\
\text { feed rate and inversely with the cutting speed }\end{array}$ \\
\hline [6] & $\begin{array}{l}\text { Mia and Dhar, } \\
\text { (2016) }\end{array}$ & $\begin{array}{l}\text { Cutting Conditions, Cutting Speed, } \\
\text { Depth of Cut and Part Hardness }\end{array}$ & Surface Roughness & $\begin{array}{l}\text { High-pressure coolant reduced surface roughness } \\
\text { through efficient cooling and lubrication }\end{array}$ \\
\hline [7] & $\begin{array}{l}\text { Basheer et al. } \\
\qquad(2008)\end{array}$ & $\begin{array}{l}\text { Depth of Cut, Particle Size, and Nose } \\
\text { Radius }\end{array}$ & $\begin{array}{l}\text { Surface Roughness and } \\
\text { Material Removal Rate }\end{array}$ & $\begin{array}{l}\text { The best surface quality was obtained with the lowest } \\
\text { feed rate value, the smallest particle size, and the } \\
\text { largest tooltip radius }\end{array}$ \\
\hline$[8]$ & $\begin{array}{c}\text { Beatrice et al. } \\
(2014)\end{array}$ & $\begin{array}{l}\text { Cutting Speed, Feed Rate and Depth of } \\
\text { Cut }\end{array}$ & Surface Roughness & $\begin{array}{l}\text { The highly efficient feedback propagation algorithm as } \\
\text { a method for network training }\end{array}$ \\
\hline [9] & $\begin{array}{l}\text { Abeesh et al. } \\
(2008)\end{array}$ & $\begin{array}{l}\text { Feed Rate, Particle Size, Tool Nose } \\
\text { Radius }\end{array}$ & Surface Roughness & $\begin{array}{l}\text { The predicted responses of the ANN model are in very } \\
\text { good agreement with the experimental data }\end{array}$ \\
\hline$[10]$ & $\begin{array}{c}\text { Erzurumlu and } \\
\text { Oktem (2007) } \\
\end{array}$ & $\begin{array}{l}\text { Feed Rate, Cutting Speed, Axial-Radial } \\
\text { Depth of Cut, Machining Tolerance }\end{array}$ & Surface Roughness & $\begin{array}{l}\text { The ANN model leads to a slightly more accurate } \\
\text { surface roughness prediction than a conventional model }\end{array}$ \\
\hline [11] & Davim et al. (2008) & Feed Rate, Cutting Speed, Depth of Cut & $\begin{array}{l}\text { Surface Roughness and } \\
\text { Material Removal Rate }\end{array}$ & $\begin{array}{l}\text { ANN can capture any degree of non-linearity that exists } \\
\text { between the process response and input parameters, and } \\
\text { exhibits good generalization }\end{array}$ \\
\hline [12] & $\begin{array}{l}\text { Kant and Sangwan, } \\
\text { (2015) }\end{array}$ & $\begin{array}{l}\text { Cutting Speed, Feed Rate, Depth of Cut } \\
\text { and Tool Flank Wear }\end{array}$ & $\begin{array}{l}\text { Power Consumption } \\
\text { and Surface Roughness }\end{array}$ & $\begin{array}{l}\text { The ANN model together with a genetic algorithm } \\
\text { leads to a minimum surface roughness value of } 0.099 \\
\text { m. }\end{array}$ \\
\hline [13] & $\begin{array}{l}\text { Vishnu, Yohan and } \\
\text { Sankaraiah, (2018) }\end{array}$ & $\begin{array}{l}\text { Tool Tip Radius, Cutting Speed, } \\
\text { Advance Speed, Depth of Cut (Axial and } \\
\text { Radial) }\end{array}$ & $\begin{array}{l}\text { Material Removal Rate } \\
\text { and Surface Roughness }\end{array}$ & $\begin{array}{l}\text { The most dominant parameter for surface roughness is } \\
\text { the feed rate, while the one with the least effect is the } \\
\text { cutting speed }\end{array}$ \\
\hline [14] & $\begin{array}{l}\text { Ozel and Karpat, } \\
\qquad(2005)\end{array}$ & $\begin{array}{l}\text { Cutting Speed, Feed Rate, Depth of Cut, } \\
\text { Part Hardness, Cutting Time, Tool Tip } \\
\text { Angle, Cutting Distance }\end{array}$ & $\begin{array}{l}\text { Surface Roughness and } \\
\text { Tool Flank Wear }\end{array}$ & $\begin{array}{l}\text { There are two main effects that lead to surface } \\
\text { roughness degradation: adhesion and plowing. The } \\
\text { frictional interaction between the tool and the } \\
\text { workpiece has a significant impact on surface quality }\end{array}$ \\
\hline [15] & $\begin{array}{l}\text { D'Mello, Pai and } \\
\text { Puneet, (2017) }\end{array}$ & $\begin{array}{l}\text { Cutting Speed, Feed Rate and Depth of } \\
\text { Cut }\end{array}$ & $\begin{array}{l}\text { Production Time and } \\
\text { Surface Roughness }\end{array}$ & $\begin{array}{l}\text { They use metaheuristic algorithms. The results show } \\
\text { that the bat algorithm produces better optimization, } \\
\text { compared to the firefly algorithm and particle swarm } \\
\text { optimization }\end{array}$ \\
\hline [16] & $\begin{array}{c}\text { Paturi and } \\
\text { Devarasetti (2018) }\end{array}$ & $\begin{array}{l}\text { Cutting Speed, Feed Rate, Depth of Cut, } \\
\text { Tool Tip Angle, Cutting Angle }\end{array}$ & $\begin{array}{l}\text { Surface Roughness and } \\
\text { Tool Flank Wear }\end{array}$ & $\begin{array}{l}\text { Surface roughness has a decreasing tendency towards a } \\
\text { increase in cutting speed, while changes in feed rate } \\
\text { appear not to be significant }\end{array}$ \\
\hline [17] & $\begin{array}{l}\text { Nalbant et al. } \\
(2009)\end{array}$ & Coating Tools, Feed Rate, Cutting Speed & Surface Roughness & $\begin{array}{l}\text { The results from the ANN are very close to the } \\
\text { experiment-based results with an acceptable accuracy }\end{array}$ \\
\hline [18] & Al-Ahmari (2007) & $\begin{array}{l}\text { Cutting Speed, Feed Rate, Depth of Cut, } \\
\text { Tool Nose Radius }\end{array}$ & $\begin{array}{l}\text { Tool Life and Surface } \\
\text { Roughness }\end{array}$ & $\begin{array}{l}\text { The ANN model is better than linear regression } \\
\text { analysis techniques and RSM for predicting tool life } \\
\text { and cutting force models }\end{array}$ \\
\hline [19] & $\begin{array}{l}\text { Sanjay and Jyothi } \\
(2006)\end{array}$ & $\begin{array}{l}\text { Drill diameter, Cutting Speed, Feed } \\
\text { Rate, Machining Time }\end{array}$ & Surface Roughness & $\begin{array}{l}\text { ANN has shown that it is capable of generalization and } \\
\text { is effective in surface roughness analysis }\end{array}$ \\
\hline [20] & $\begin{array}{c}\text { Dahbi, El } \\
\text { Moussami and } \\
\text { Ezzine, }(2016) \\
\end{array}$ & $\begin{array}{l}\text { Depth of Cut, Cutting Speed, Feed Rate, } \\
\text { and Tool Nose Radius }\end{array}$ & Surface Roughness & $\begin{array}{l}\text { It is crucial to consider the effects of interactions } \\
\text { between parameters for surface roughness optimization, } \\
\text { for example, between feed rate and tool nose radius. }\end{array}$ \\
\hline [21] & $\begin{array}{c}\text { Sivaiah and } \\
\text { Chakradhar, (2019) }\end{array}$ & $\begin{array}{l}\text { ig Speed, Feed Rate, Depth of Cut, } \\
\text { int Type }\end{array}$ & Surface Roughness & $\begin{array}{l}\text { Results show that surface roughness is significantly } \\
\text { affected by cutting speed }(54.12 \%) \text {. }\end{array}$ \\
\hline [22] & $\begin{array}{c}\text { Cus and Zuperl } \\
\text { (2006) } \\
\end{array}$ & Cutting Speed, Feed Rate, Depth of Cut & Surface Roughness & $\begin{array}{l}\text { ANN provides a sufficient approximation to the true } \\
\text { optimal solution for minimize surface roughness }\end{array}$ \\
\hline [23] & $\begin{array}{l}\text { Kohli and Dixit } \\
\qquad \text { (2005) }\end{array}$ & $\begin{array}{l}\text { Cutting Speed, Feed Rate, Depth of Cut, } \\
\text { Radial Vibration }\end{array}$ & $\begin{array}{l}\text { Surface Roughness and } \\
\text { Material Removal Rate }\end{array}$ & $\begin{array}{l}\text { ANN is able to make an accurate prediction of surface } \\
\text { roughness by utilizing a small-sized training and testing } \\
\text { dataset }\end{array}$ \\
\hline [24] & $\begin{array}{l}\text { Ezugwu et al. } \\
(2005)\end{array}$ & $\begin{array}{l}\text { atting Speed, Feed Rate, Depth of Cut, } \\
\text { atting Time, Coolant Pressure }\end{array}$ & Surface Roughness & $\begin{array}{l}\text { ANN gives a very good agreement between predicted } \\
\text { and experimentally measured process parameters }\end{array}$ \\
\hline [25] & $\begin{array}{l}\text { Grzesick and Brol } \\
\qquad(2003)\end{array}$ & $\begin{array}{l}\text { Feed Rate, Spindle Speed, Depth of Cut, } \\
\text { Cutting Time, Cutting Force }\end{array}$ & Surface Roughness & $\begin{array}{l}\text { ANN gives a close agreement between the real data and } \\
\text { predicted values of surface finish within } \pm 10 \% \text { of the } \\
\text { experimental values }\end{array}$ \\
\hline [26] & $\begin{array}{l}\text { Debnath, Reddy } \\
\text { and Sok Yi, (2016) }\end{array}$ & $\begin{array}{l}\text { Cutting Speed, Feed Rate, Depth of Cut, } \\
\text { Cutting Fluid Condition }\end{array}$ & $\begin{array}{l}\text { Surface Roughness and } \\
\text { Tool Flank Wear }\end{array}$ & $\begin{array}{l}\text { Optimal cutting conditions for surface roughness are a } \\
\text { high level of cutting speed, a medium level of cutting } \\
\text { depth and a high-speed cutting fluid flow (LFHV). }\end{array}$ \\
\hline$[27]$ & Kant and Sangwan & Cutting Speed, Feed Rate, Depth of Cut & Surface Roughness & The results indicate that the feed rate is the most \\
\hline
\end{tabular}




\begin{tabular}{|c|c|c|c|c|}
\hline & Article & Parameters used & Objective Function & Remarks \\
\hline & (2014) & & & $\begin{array}{l}\text { significant machining parameter for surface roughness, } \\
\text { followed by depth of cut and cutting speed. }\end{array}$ \\
\hline [28] & Aouici et al. (2011) & $\begin{array}{l}\text { Cutting Speed, Feed Rate, Depth of Cut, } \\
\text { Part Hardness }\end{array}$ & $\begin{array}{l}\text { Surface Roughness and } \\
\text { Cutting Force }\end{array}$ & $\begin{array}{l}\text { The best suggested ranges of the parameters variables } \\
\text { for industrial production are cutting speed }(120-240) \text {, } \\
\text { feed rate }(0.08-0.16) \text {, depth of cut }(0.15-0.45) \text {, part } \\
\text { hardness }(40-50) \text {. }\end{array}$ \\
\hline [29] & $\begin{array}{l}\text { Zuperl and Cus } \\
\text { (2003) }\end{array}$ & Cutting Speed, Feed Rate, Depth of Cut & Surface Roughness & $\begin{array}{l}\text { ANN provides a sufficient approximation to the true } \\
\text { optimal solution }\end{array}$ \\
\hline [30] & Tansel et al. (2006) & $\begin{array}{l}\text { Cutting Speed, Feed Rate, Radial Depth } \\
\text { of Cut }\end{array}$ & $\begin{array}{l}\text { Surface Roughness and } \\
\text { Material Removal Rate }\end{array}$ & $\begin{array}{l}\text { The ANN model represents the data well and has a very } \\
\text { small error for the training cases }\end{array}$ \\
\hline [31] & Oktem et al. (2006) & $\begin{array}{l}\text { Cutting speed, feed rate, axial-radial } \\
\text { depth of cut, machining tolerance }\end{array}$ & Surface Roughness & $\begin{array}{l}\text { ANN presents a very good performance for surface } \\
\text { roughness response value }\end{array}$ \\
\hline
\end{tabular}

Source: Own work elaboration.

The modeling techniques for the prediction of the indicators (stage i) can be categorized as experimental models, analytical models, and artificial intelligence models. The most commonly used approaches are statistical regressions, genetic algorithms (GA), and artificial neural networks (ANNs). Statistical regressions are useful techniques for modeling and calculating the effect that variables and their interactions have on a response. However, they have the limitation of only being able to accurately describe linear relationships [5]. On the other hand, GAs are a series of organized steps that describe the process to be followed for an evolving population from which the best one will be chosen, according to some criteria [13]. However, the evaluation of GAs compared to ANNs on highly complex problems can become too expensive in terms of time and resources. Also, there might be cases where depending on the parameters used, the algorithm may not converge on an optimal solution or end in premature convergence with unsatisfactory results. For this reason ANNs have recently become the preferred model by most researchers looking to develop a model that establishes optimal machining conditions [32][35]. On the other hand, ANNs are extensively used for modeling the machining processes because of their efficiency to establish optimal conditions [8]-[10], [13]-[15], [26]-[31]. Among the different studies shown in Table 1 that used this technique to model the machining process, it was found that the accuracy of ANN models usually falls between $95 \%$ and $99 \%$. This table shows the variables that were taken into account for the work, the applied objective functions, and some findings of the studies.

Once the objectives are modeled as functions of the machining parameters (stage i), the procedure can be complemented by implementing a multi-objective optimization technique aiming for the optimal solution. Table 2 enumerates the previous studies on implementing different techniques in the optimization of machining processes. These studies have used evolutionary and metaheuristic techniques such as Particle Swarm Optimization (PSO) [36], [45], [49], Genetic Algorithm (GA) [39], [42], [55]-[58], Simulated Annealing (SA) [41], [43], [54] and Ant Colony Optimization (ACO) [38], [48], [51] in order to conclude about the appropriate selection of the cutting parameters in the nonlinear and multidimensional problems of the cutting process. All of those models are techniques inspired by nature and solve problems through processes that emulate the behaviors of 
living organisms. For example, ACO is a probabilistic technique to solve computational problems that can be reduced to finding good paths through graphs while SA is an optimization method that mimics the slow cooling of metals, which is characterized by a progressive reduction in the atomic movements that reduce the density of lattice defects until a lowest-energy state is reached. Our of these techniques, PSO has comparably yielded better results [36], [39], [41], [43], [55]. Hence in this work we are going to use those techniques for our application.

Another reason that supports the selection of the PSO method for this study over, for example, ACO is that the second one is more likely to be trapped in a local optimum. This behavior occurs because the structure of ACO tends to search the shortest road and the 'ants' tend to follow the same path, while the PSO particles follow different paths and make their decisions based on both their own and collective learning. In PSO, this individual and collective learning is the key for improving the interactions between the individuals of the population as well as the progress of the solution, since the particles retain the knowledge of the best solutions found.

Table 2. Studies related to the optimization techniques of cutting processes.

\begin{tabular}{|c|c|c|c|c|c|}
\hline \multicolumn{2}{|c|}{ Author, Year } & Parameters used & $\begin{array}{l}\text { Objective } \\
\text { Functions }\end{array}$ & $\begin{array}{c}\text { Optimization } \\
\text { Technique }\end{array}$ & Remarks \\
\hline$[36]$ & $\begin{array}{c}\text { Bharathi and } \\
\text { Baskar } \\
(2010)\end{array}$ & $\begin{array}{l}\text { Cutting Speed, Feed Rate and Depth } \\
\text { of Cut }\end{array}$ & $\begin{array}{l}\text { Machining Time } \\
\text { and Surface } \\
\text { Roughness }\end{array}$ & PSO & $\begin{array}{l}\text { PSO is capable of selecting appropriate machining } \\
\text { parameters for turning operation }\end{array}$ \\
\hline [37] & $\begin{array}{l}\text { Farahnakian } \\
\text { et al. (2011) }\end{array}$ & $\begin{array}{l}\text { Cutting Speed, Feed Rate and Depth } \\
\text { of Cut }\end{array}$ & $\begin{array}{l}\text { Cutting Forces and } \\
\text { Surface Roughness }\end{array}$ & PSONN & $\begin{array}{l}\text { A very good training capacity of the proposed } \\
\text { PSONN algorithm was found. }\end{array}$ \\
\hline$[38]$ & $\begin{array}{l}\text { Yang et al. } \\
\text { (2011) }\end{array}$ & $\begin{array}{l}\text { Number of passes, Depth of Cut in } \\
\text { each pass, Cutting Speed and Feed } \\
\text { Rate }\end{array}$ & Production Cost & $\mathrm{ACO}$ & $\begin{array}{l}\text { The proposed schemes may be a promising tool } \\
\text { for the optimization of machining process } \\
\text { parameters }\end{array}$ \\
\hline [39] & $\begin{array}{l}\text { Ganesan et } \\
\text { al. (2011) }\end{array}$ & $\begin{array}{l}\text { Cutting Speed, Feed Rate and Depth } \\
\text { of Cut }\end{array}$ & Production Time & PSO and GA & PSO produces better results than GA \\
\hline [40] & $\begin{array}{l}\text { Razfar et al. } \\
\qquad(2010)\end{array}$ & $\begin{array}{l}\text { Cutting Speed, Feed Rate, Depth of } \\
\text { Cut and Engagement }\end{array}$ & Surface Roughness & PSO & $\begin{array}{l}\text { A good agreement is observed between the values } \\
\text { predicted by the PSONNOS algorithm and } \\
\text { experimental measurements }\end{array}$ \\
\hline [41] & $\begin{array}{c}\text { Zheng and } \\
\text { Ponnabalam } \\
\text { (2010) }\end{array}$ & $\begin{array}{l}\text { Feed Rate, Cutting Speed and Depth } \\
\text { of Cut }\end{array}$ & Production Cost & PSO, GA and SA & PSO performs better than GA and SA \\
\hline$[42]$ & $\begin{array}{l}\text { Rao et al. } \\
\text { (2010) }\end{array}$ & $\begin{array}{l}\text { Amplitude of ultrasonic vibration, } \\
\text { frequency of ultrasonic vibration, } \\
\text { mean diameter of abrasive particles, } \\
\text { volumetric concentration of abrasive } \\
\text { particles, and static feed force. }\end{array}$ & $\begin{array}{l}\text { Material Removal } \\
\text { Rate }\end{array}$ & GA & $\begin{array}{l}\text { The results of the presented algorithms are } \\
\text { compared with the previously published results } \\
\text { obtained by using GA }\end{array}$ \\
\hline [43] & $\begin{array}{c}\text { Bharathi and } \\
\text { Baskar } \\
(2010)\end{array}$ & $\begin{array}{l}\text { Number of passes, Cutting Speed, } \\
\text { Feed Rate and Depth of Cut }\end{array}$ & $\begin{array}{l}\text { Production cost and } \\
\text { Material Removal } \\
\text { Rate }\end{array}$ & PSO, GA and SA & $\begin{array}{l}\text { PSO give the best results compared to GA and SA } \\
\text { in the three turning operations. }\end{array}$ \\
\hline [44] & $\begin{array}{l}\mathrm{Xi} \text { and Liao } \\
\text { (2009) }\end{array}$ & Feed Rate and Cutting Speed & $\begin{array}{l}\text { Machining Time, } \\
\text { Machining } \\
\text { Accuracy and } \\
\text { Machining Cost }\end{array}$ & $\mathrm{ACO}$ and GA & $\begin{array}{l}\text { The optimized cutting parameters values are better } \\
\text { to meet the user's optimization goals }\end{array}$ \\
\hline$[45]$ & $\begin{array}{l}\text { Escamilla et } \\
\text { al. (2009) }\end{array}$ & $\begin{array}{l}\text { Cutting Speed, Feed Rate and Depth } \\
\text { of Cut }\end{array}$ & Surface Roughness & PSO & $\begin{array}{l}\text { PSO optimization can be successfully applied to } \\
\text { multi-objective optimization of titanium's } \\
\text { machining process }\end{array}$ \\
\hline [46] & $\begin{array}{l}\text { Ciurana et } \\
\text { al. }(2009)\end{array}$ & $\begin{array}{l}\text { Laser Fluence, Position of Focal } \\
\text { Plane, Laser Spot Size, Translation } \\
\text { Distance between subsequent laser } \\
\text { pulses }\end{array}$ & $\begin{array}{l}\text { Surface Roughness } \\
\text { and Volume Error }\end{array}$ & PSO & $\begin{array}{l}\text { The proposed models and swarm optimization } \\
\text { approach are suitable to identify optimum process } \\
\text { settings }\end{array}$ \\
\hline [47] & Prakasvudhi & Cutting Speed, Feed Rate and Depth & Surface Roughness & PSO & $\mathrm{CNC}$ and milling can achieve the desired surface \\
\hline
\end{tabular}




\begin{tabular}{|c|c|c|c|c|c|}
\hline \multicolumn{2}{|c|}{ Author, Year } & \multirow[t]{2}{*}{ Parameters used } & \multirow{2}{*}{\begin{tabular}{|c|} 
Objective \\
Functions \\
and Productivity
\end{tabular}} & \multirow[t]{2}{*}{$\begin{array}{c}\text { Optimization } \\
\text { Technique }\end{array}$} & \multirow[b]{2}{*}{$\begin{array}{l}\text { roughness and also maximize } \\
\text { simultaneously }\end{array}$} \\
\hline & $\begin{array}{l}\text { sarn et al. } \\
(2009)\end{array}$ & & & & \\
\hline [48] & $\begin{array}{l}\text { Srinivas et } \\
\text { al. (2009) }\end{array}$ & $\begin{array}{l}\text { Feed Rate, Cutting Speed and Depth } \\
\text { of Cut }\end{array}$ & $\begin{array}{l}\text { Production Cost and } \\
\text { Machining Time }\end{array}$ & $\mathrm{ACO}$ & $\begin{array}{l}\text { In multi-pass turning the best solution in each } \\
\text { generation is obtained by comparing the unit } \\
\text { production cost and the total non-dimensional } \\
\text { constraint violation among all of the particles }\end{array}$ \\
\hline [49] & $\begin{array}{l}\text { Li et al. } \\
(2008)\end{array}$ & Spindle Speed and Feed Rate & $\begin{array}{c}\text { Cutting Force, Tool- } \\
\text { life, Surface } \\
\text { Rougness and } \\
\text { Cutting Power }\end{array}$ & PSO & $\begin{array}{l}\text { PSO in optimizing process parameters can } \\
\text { converge quickly to a consistent combination of } \\
\text { spindle speed and feed rate }\end{array}$ \\
\hline$[50]$ & $\begin{array}{c}\text { Duran et al. } \\
\text { (2008) }\end{array}$ & $\begin{array}{l}\text { Cutting Speed, Power, Feed Rate and } \\
\text { Depth of Cut }\end{array}$ & Tool Geometry & PSO & $\begin{array}{l}\text { The selection of the appropriate cutting tool } \\
\text { geometry is possible in real world environments }\end{array}$ \\
\hline$[51]$ & $\begin{array}{c}\text { Chen and } \mathrm{Li} \\
\text { (2008) }\end{array}$ & Depth of Cut, Feed Rate and Grit Size & $\begin{array}{l}\text { Material Removal } \\
\text { Rate }\end{array}$ & $\mathrm{ACO}$ & $\begin{array}{l}\text { The proposed algorithm is an effective method for } \\
\text { grinding process optimization problem }\end{array}$ \\
\hline [52] & $\begin{array}{l}\text { Zhao et al. } \\
\text { (2008) }\end{array}$ & Spindle Speed and Feed Rate & Cutting Forces & PSO & $\begin{array}{l}\text { The machining process with constant cutting force } \\
\text { can be achieved via process parameters } \\
\text { optimization based on virtual machining }\end{array}$ \\
\hline [53] & $\begin{array}{l}\text { Liu and } \\
\text { Huang } \\
(2008)\end{array}$ & Feed Rate and Cutting Speed & Cost performance & PSO & $\begin{array}{l}\text { PSO is relevant for solving complicated nonlinear } \\
\text { problem }\end{array}$ \\
\hline$[54]$ & $\begin{array}{l}\text { Zuperl et al. } \\
\quad(2007)\end{array}$ & Feed Rate and Cutting Speed & Cutting Forces & GA and SA & $\begin{array}{l}\text { Compared with GA and SA, the proposed } \\
\text { algorithm can improve the quality of the solution } \\
\text { while speeding up the convergence process }\end{array}$ \\
\hline$[55]$ & $\begin{array}{l}\text { Huang et al. } \\
\text { (2007) }\end{array}$ & Spindle Speed, Feed Rate and Width & Tool wear & $\begin{array}{l}\text { MPSO, BP-NN, WNN } \\
\text { and GA }\end{array}$ & $\begin{array}{l}\text { The MPSO-trained WNN has a superior } \\
\text { performance than BP-NN, conventional WNN, } \\
\text { and GA-based WNN }\end{array}$ \\
\hline
\end{tabular}

Source: Yusup et al. [58].

The PSO algorithm was originally developed by Kennedy and Eberhart [38] to solve continuous optimization problems [57]. In this model, the swarm is composed of volumeless particles with stochastic velocities, each of which represents a feasible solution. Then, the algorithm moves through all particles evaluating the objective functions until it finds the optimum in the solution space. The advantages of PSO are that it requires uncomplicated mathematical operators; therefore, it is computationally economical in terms of both memory requirements and speed according to Yusup [58]. Another advantage of PSO, as discussed in Karpat \& Özel [59] is that the information sharing mechanism among the particles in PSO is significantly different from the chromosomes in GAs. In GAs, the entire group moves toward an optimal solution area, while in PSO only the global best or local best solution is reported to the other particles in a swarm. Therefore, evolution only looks for the best solution and the swarm tends to converge to the best solution quickly and efficiently.

Taking all these facts as a whole, it is clear that a lot of research has been done and some prediction models have been developed to minimize $R_{a}$ in machining processes. However, most of these models only take into account three cutting parameters, which are almost always cutting speed, depth of cut, and feed rate. One of the machining parameters that drastically affects the part quality is the cutting tool condition. The cutting tool condition is usually taken into account by the tool edge and nose radius, which deteriorates with the machining time and usage. However, tool nose radius is more influential in the turning process and —as in this work we are using the turning manufacturing process as our 
experimental methodology - tool nose radius is considered as one of our decision variables of the process. In addition, most of those studies focus on predicting $R_{a}$ and MRR values based on established conditions but they do not pay attention to the development of models that suggest optimal cutting conditions according to the restrictions of the problem. Therefore, we consider herein the cutting velocity, feed rate, depth of cut, and tool nose radius as our parameters for decision

We will use the turning machining process for data collection and develop/train an artificial neural network for the prediction of $R_{a}$ in machining processes, in which the cutting speed, depth of cut, feed rate, and nose radius are taken into account as the decision variables of the process. Next, the multi-objective optimization model PSO will be implemented in order to find the cutting conditions that minimize $R_{a}$ and simultaneously maximize MRR. This study seeks to achieve a better approximation to the multiple challenges faced by the manufacturing industry and to obtain more accurate and useful results when it comes to turning processes.

\section{Methodology}

The turning manufacturing process is performed on Aluminum. A full factorial design of experiments was executed to collect the data. Using these data, a predictive ANN model was developed in order to relate the machining parameters to the response variable $\left(R_{a}\right)$ of the turning process. Next, we formulated a multi-objective optimization model that would help in calculating the optimal cutting parameters for maximizing MMR and minimizing $R_{a}$

A conventional lathe machine was used to perform the turning manufacturing process, which is one of the most common machining process (Figure 1). The design factors are the cutting parameters, i.e., cutting speed, depth of cut, feed rate, and the cutting tool nose radius ( 4 factors), each at three levels except for the nose radius that was taken at two levels (Table 3). Such factors and their levels result in a $2 \times 3^{\wedge} 3$ factorial design that was replicated five times.

Figure 1. Conventional lathe machine (turning process).



Source: Own work elaboration. 


\section{Material and Experimental Technique}

The material used for the study was Aluminum Alloy 6063 (AA 6063), which was fully annealed by heat treatment in order to homogenize the material properties. To do this, the material was subjected to an average temperature of $415^{\circ} \mathrm{C}$ for one hour. The samples were 2-inch diameter Aluminum bars (Figure 2). Different cuts were on them made in order to reach a cutting length of $10 \mathrm{~mm}$ for all the samples. We selected AA 6063 to perform the experiments due to the extensive application of this material in the industry because of its properties such as lightness, good resistance-to-weight ratio, and high electrical and thermal conductance. Changing the factor levels according to Table 3 , the factor treatment combinations resulted in 24 sample conditions repeated five times. The cutting tools used were VBGT160404-AK and VBGT160408-AK (Figure 3). The samples were then examined in order to measure the surface roughness. The surface roughness $R_{a}$ of the samples was measured using a rough meter model Mitutoyo on the surface as shown in Figure 4. This device gives the arithmetic value of the roughness of the mean surface $(\mu \mathrm{m})$ of the machined surface based on ISO 4287-1997 standards (the unit of measurement is $\mu \mathrm{m})$.

Figure 2. AA 6063 sample bar.

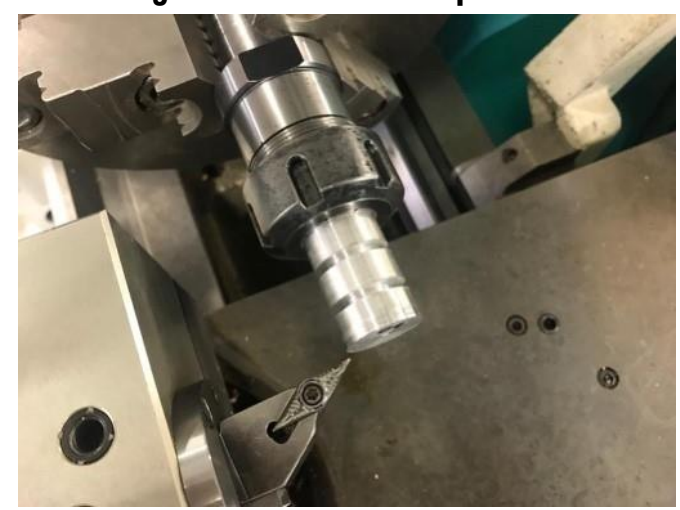

Source: Own work elaboration.

Figure 3. Cutting tools.

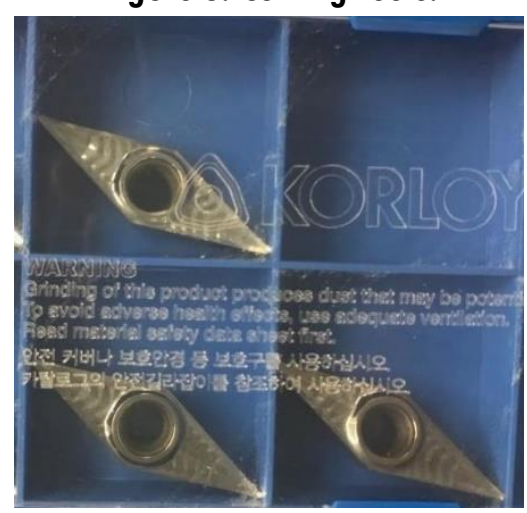

Source: 0 wn work elaboration.
Figure 4. Rough meter.



Source: Own elaboration. 


\section{Data Collection}

As explained before, a complete factorial design was used to obtain the data using different combinations of the design factors cutting speed, depth of cut, and feed rate at three levels and the tool nose radius at two levels. Each treatment was replicated five times in order to account for the variability in the process. The levels are described in Table 3. The experimental values are listed in Table A1, in the Appendix. The values in this table are the averages of the five replications for each treatment combination of the considered design factors.

Table 3. Parameters of turning process (design factors) and their levels.

\begin{tabular}{cccccc}
\hline \multirow{2}{*}{ Symbol } & Parameter & \multirow{2}{*}{ Units } & \multicolumn{3}{c}{ Levels } \\
\cline { 4 - 6 } & & & $\mathbf{1}$ & $\mathbf{2}$ & $\mathbf{3}$ \\
\hline $\boldsymbol{v}$ & Cutting speed & $\mathrm{rpm}$ & 640 & 1120 & 1584 \\
\hline $\boldsymbol{d}$ & Depth of cut & $\mathrm{mm}$ & 0.2 & 0.6 & 1.0 \\
\hline $\boldsymbol{f}$ & Feed rate & $\mathrm{mm} / \mathrm{rev}$ & 0.04 & 0.08 & 0.12 \\
\hline $\boldsymbol{r}$ & Tool nose radius & $\mathrm{mm}$ & 0.4 & 0.8 & - \\
\hline
\end{tabular}

Source: Own work elaboration.

Having collected all the results from the experiments, an Analysis of Variance (ANOVA) along with linear regression was performed in order to evaluate significance of the design factors (cutting parameters) for the observation surface roughness $R_{a}$. This analysis is presented in Table 4. The regression model (Equation 1) was implemented in RStudio ${ }^{1}$ and based on the obtained results we can conclude that all variables, under a significance level of $1 \%$, are statistically significant. In addition, it was evident that the variable that has the greatest influence on $R_{a}$ is the feed rate, followed by velocity, then nose radius and, finally, the depth of cut.

Table 4. ANOVA.

\begin{tabular}{cccccc}
\hline Factor & Df & Sum Sq & Mean Sq & F Value & Pr $(>\mathbf{F})$ \\
\hline Cutting speed & 1 & 1.635 & 1.635 & 70.050 & $3.36 \times 10^{-15}$ \\
\hline Depth of cut & 1 & 12.222 & 12.222 & 523.750 & $<2 \times 10^{-16}$ \\
\hline Feed Rate & 1 & 0.160 & 0.160 & 6.845 & 0.0094 \\
\hline Nose Radius & 1 & 0.854 & 0.854 & 36.616 & $4.89 \times 10^{-09}$ \\
\hline Residuals & 265 & 6.184 & 0.023 & & \\
\hline
\end{tabular}

Source: Own work elaboration.

$$
R_{a}=\beta_{0}+\beta_{1} v+\beta_{2} d+\beta_{3} f+\beta_{4} r
$$


Regarding the reliability of the results obtained from the linear regression model, we can highlight that the coefficient of determination (R2) of the model was 0.7063 , while the adjusted coefficient of determination obtained was 0.7019 . These values allow us to affirm that the estimations of the proposed regression could be adjusted with relative precision to the surface roughness variable. On the other hand, we can highlight that the VIF of the model is 3.4, which means that the model does not present multicollinearity problems. Additionally, it is noteworthy that the correlation coefficients have been calculated and resulted in values close to zero. Finally, when observing the coefficients (betas) deducted by the model, it is evident that the most influential variable is the feed rate (a change in that variable implies a change in the surface roughness, at least, 3 times greater than that produced by any change in any other variable), followed by the cutting speed, nose radius and, finally, depth of cut.

Having found that the four variables explain (and the magnitude in which each one does it) the response variable $R_{a}$, the next step was to develop the Artificial Neural Network model.

\section{Artificial Neural Network}

Artificial neural network is a non-linear mapping system inspired by the functions of a human brain [56]. In order to predict $R_{a}$ a multilayer ANN model was chosen and the resilience Back Propagation algorithm was used to train the network due to its wide application [60]. The network was built with three layers, the input, the output and a hidden layer. Choosing such scheme, each neuron of the input layer can take only one value per iteration and this value is transferred to all neurons of the hidden layer, which are interconnected by synaptic weights to the output layer, assuring that every neuron of the hidden layer is connected to the output layer neuron. The ANN with one hidden layer was selected due to the greater interpretability as well as the reduction in the error (the error is supposed to decrease with lower numbers of layers). The input neurons are the type of cutting speed, depth of cut, feed rate, cutting speed, and the tool nose radius whereas the output neuron is the surface roughness.

The ANN was implemented in RStudio. The software randomly selected the weights of the network connections and was trained with 243 experimental data and was subsequently validated and tested with 27 additional experimental data. Also, the transfer function used to calibrate the weights was the Sigmoid Function as Follows:

$$
S(x)=\frac{1}{1+e^{-x}}
$$


With the data obtained from the experiments, the ANN was trained and the appropriate network structure was found by varying the number of nodes in the hidden layer. The decision criterion was choosing the network structure with the lowest mean square error (MSE) as in Equation 3 with $\widehat{R_{a}}$ equal to 0.9436 and $n$ 27. According to the results, the best structure was 4-7-1, resulting in an error of 0.5042 which was used here. It should be noted that the structures 4-6-1 with an MSE of 0.5682 and 4-4-1 with an MSE of 0.5757 were the second and third ones closest to minimum MSE. The graphical representation of the Network's structure is shown in Figure 5. Finally, it is important to highlight that a bias was added to both the hidden layer and output layer, so the network could have more flexibility in calibrating the weights.

$$
M S E=\frac{1}{n} \sum_{i=1}^{n}\left(R_{a}-\widehat{R_{a}}\right)^{2}
$$

Figure 5. Graphical representation of the network structure.

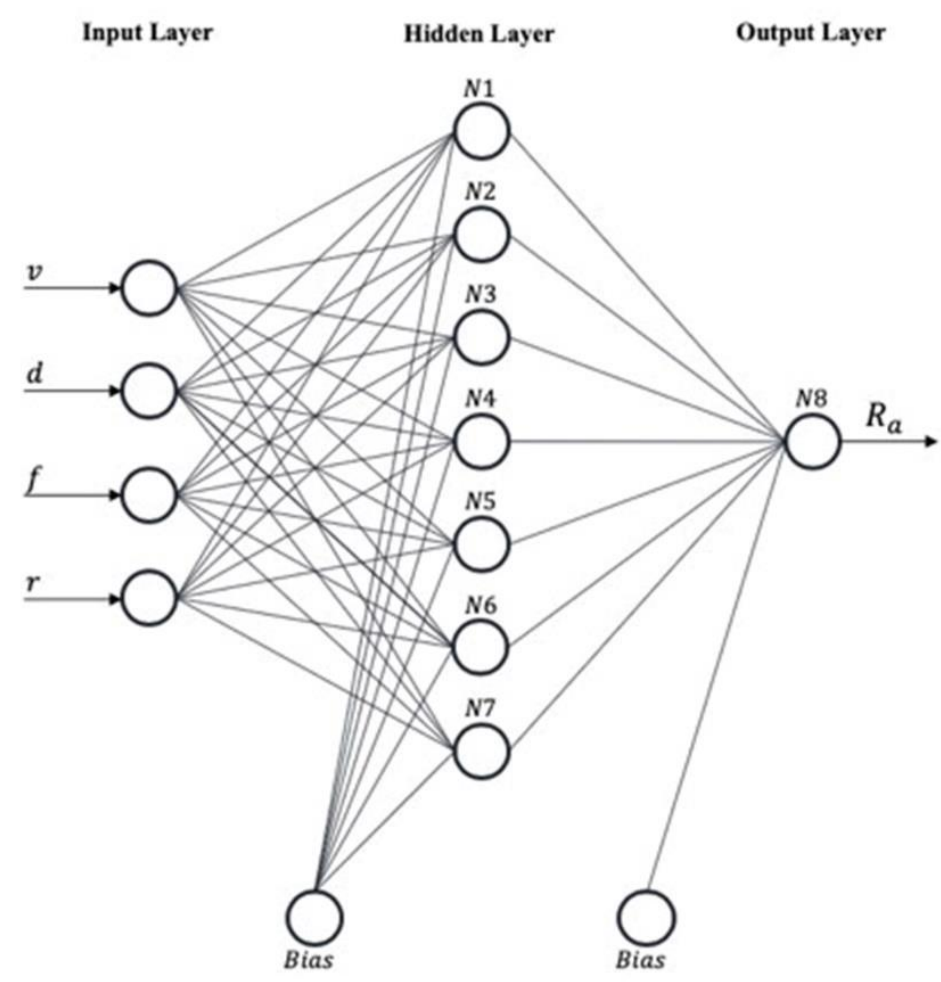

Source: Own work elaboration.

To compare the results obtained with the ANN, the values observed for $R_{a}$ were plotted against the estimated values of the response variable. As can be seen in Figure 6, the values estimated by the network had, for the most part, a huge similarity with the values observed for $R_{a}$. In addition, when performing a correlation analysis between both variables, a value 
greater than 0.9 was obtained, which confirms the similarity and validity of the values estimated by the network as compared to the values observed for $R_{a}$.

Figure 6. Real vs Predictive Ra values.

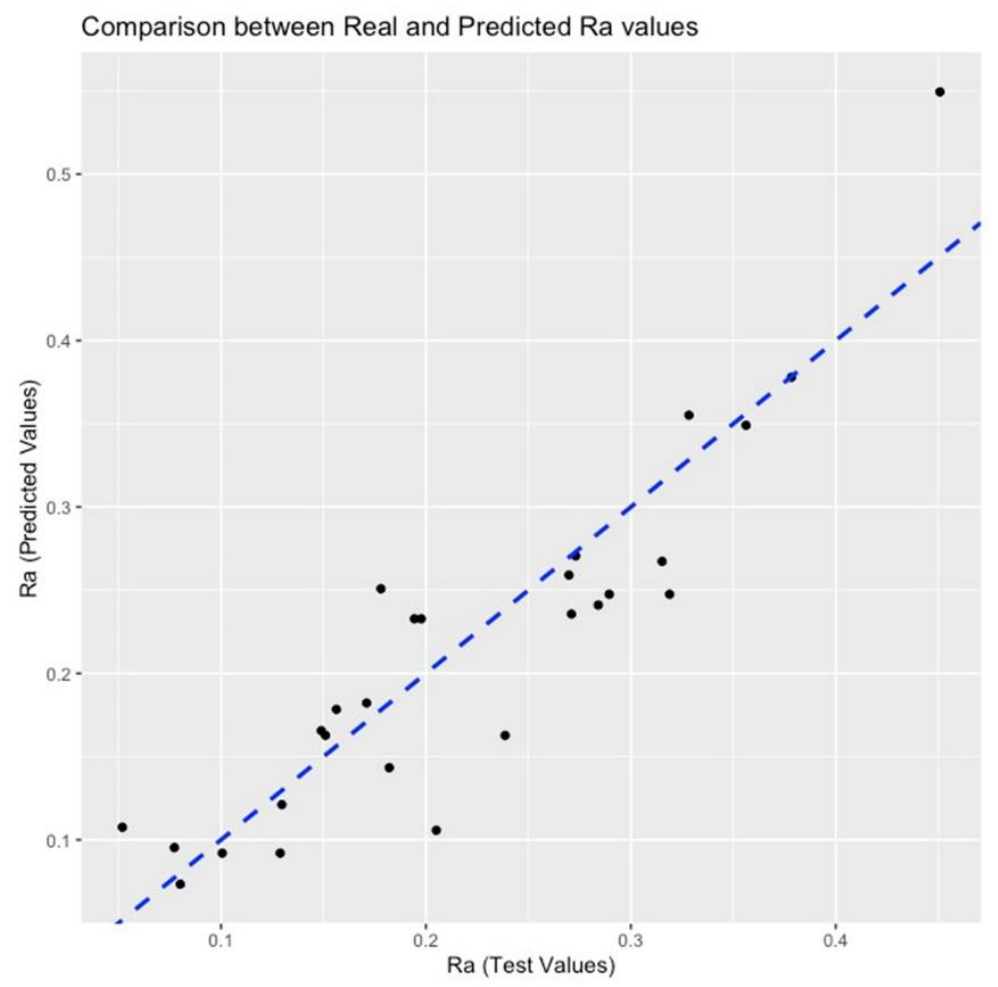

Source: Own work elaboration.

Regarding the comparison of the results obtained from the linear regression model and the artificial neural network, it is noteworthy that the MSE calculated with the predicted values by the linear regression model is 25 times greater than the MSE of the artificial neural network. These results support the selection of the artificial neural network as a model for the prediction of $R_{a}$.

\section{Multi-Objective Optimization Model}

The general formulation of multi-objective optimization problems can be written as shown in Equations 4, 5 and 6:

Minimize (or maximize)

$$
f(\mathrm{X})=\left\{f_{1}(\mathrm{X}), f_{2}(\mathrm{X}), f_{3}(\mathrm{X}), \ldots, f_{k}(\mathrm{X})\right\}
$$

Subject to

$$
g_{j}(\mathrm{X}) \leq b_{j}, \quad \text { for } j=1,2, \ldots, m
$$




$$
h_{j}(\mathrm{X})=b_{j}, \quad \text { for } j=m+1, m+2, \ldots, m+p .
$$

In these equations $f_{i}(\mathrm{X})$ denotes the $i$ th objective function, whereas $g_{j}(X)$ and $h_{j}(X)$ indicate constraints and decision variables. Also, the machining parameters and the tool geometry are shown with the vector $\mathrm{X}=\left(x_{1}, x_{2}, \ldots, x_{n}\right) \in \mathbb{R}^{\mathrm{N}}$.

When the objective functions conflict with each other, it does not exist an exact solution for the studied problem. However, the problem will have many alternative solutions. Those potential solutions are called Pareto Front [61]. Pareto Optimal Front is a set $\mathrm{X}=$ $\left\{x_{1}^{*}, x_{2}^{*}, \ldots, x_{n}^{*}\right\}$ composed of all the non-dominated solutions that comprise the Pareto Front of non-dominated solutions, which means that the Pareto Front is a vector of objective functions $f\left(\mathrm{X}^{*}\right)$, and is non-dominated if and only if it does not exist another vector $f(\mathrm{X})$, that satisfies $f(\mathrm{X}) \leq f\left(\mathrm{X}^{*}\right)$.

Although there are numerous methods to solve the multi-objective optimization problem in this study, PSO is deemed as the appropriate technique applicable to machining processes [46]. In PSO, each particle is represented by a position, the velocity vectors are defined by the number of decision variables in the problem and the modification of the position of a particle is conditioned by previous position information. According to these principles, each particle needs to know its best position ever and the best position achieved in the group. These principles can be formulated as in Equations 7 and 8:

$$
\begin{gathered}
v_{i}^{k+1}=w v_{i}^{k}+c_{1} \operatorname{rand}_{1}\left(\text { pbest }_{i}-x_{i}^{k}\right)+c_{2} \operatorname{rand}_{2}\left(\text { gbest }_{i}-x_{i}^{k}\right) \\
x_{i}^{k+1}=x_{i}^{k}+v_{i}^{k+1}
\end{gathered}
$$

where $v_{i}^{k}$ is the velocity of an agent $i$ at iteration $k, x_{i}^{k}$ the current position of an agent $i$ at iteration $k$, pbest $_{i}$ is the personal best position of an agent $i, g_{b e s t}$ is the best position in the neighborhood, rand is a random number between 0 and $1, w$ is the weighting function, and $c_{j}$ for $j=1,2$ is the learning rate.

Accordingly, the detailed four steps to follow in PSO are:

Step 1. Specify population size. Then, the initial positions and velocities of all the agents are generated randomly. Immediately, the objective function values for each agent are calculated. Finally, pbest is set as the current position of each particle and after that the best objective function value among the agents is set as gbest and this value is stored. 
Step 2. Now the new position of the agents in the solution space is determined by using equations (7) and (8). Therefore, the particles begin to move toward the space with the best objective function value, gbest.

Step 3. The objective function value is calculated for the new positions of each particle. If an agent achieves a better position, the pbest value is replaced by the current value. As in Step 1, the gbest value is selected among pbest values. If the new gbest value is better than the previous one, the gbest value is uploaded.

Step 4. Repeat Steps 1, 2, and 3 until the iteration number reaches the limit planned.

Taking all the foregoing as a whole, the optimization model developed for this study is then explained in the next subsections.

In summary, our proposed methodology can be illustrated by the flow chart in Figure 7.

Figure 7. Graphical representation of the study procedure.

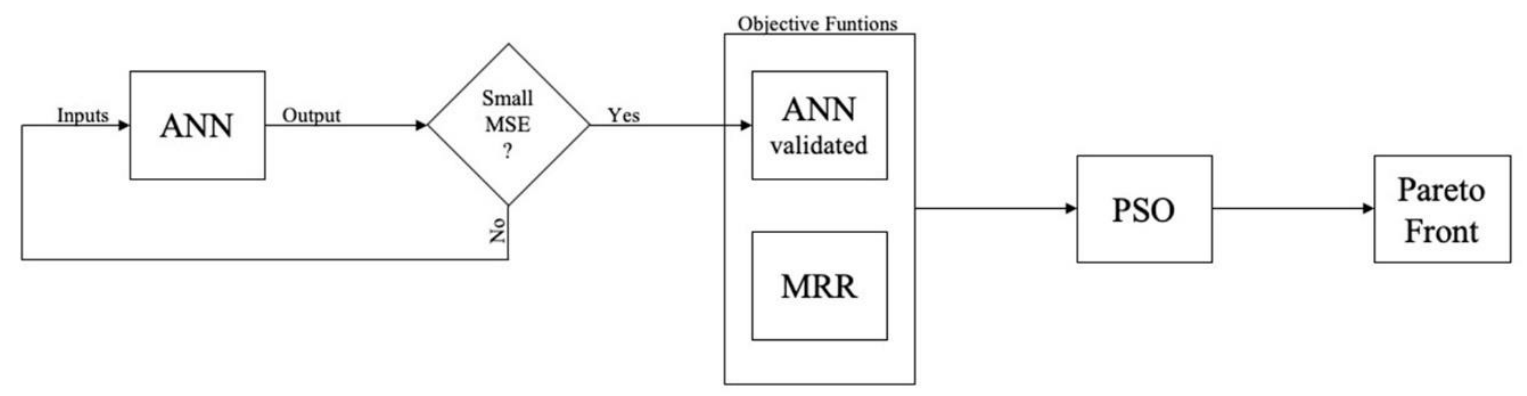

Source: Own work elaboration.

\section{Model Formulation}

For the PSO model we consider the four cutting conditions as our decision variables where $x_{1}$ is the cutting velocity, $x_{2}$ is the feed rate, $x_{3}$ is the depth of cut, and $x_{4}$ is the tool nose radius.

Our interest is to optimize a model with two objective functions; the first one is minimizing the surface roughness of the material, and the second one maximizing the Material Removal Rate. These objectives were formulated using Equations 9 and 10.

$$
\text { minimize } R_{a}=\frac{1}{1+e^{-v}}
$$




$$
\text { maximize } M R R=x_{1} * x_{2} * x_{3}
$$

where $v$ is the function obtained from the ANN. This equation is the result of the product of all the input variables and the calibrated weights of the network for each layer as follows:

$$
v=\sum_{j=1}^{7}\left(\sum_{k=1}^{2} x_{k} w_{k j}+w_{b j}\right) w_{j i}+w_{b i}
$$

Equation 10 defines the $M R R$, the amount of material removed from the workpiece per unit. It can be calculated from the volume of the material removal or from the weight difference before and after machining. With the cutting parameters MRR could be calculated as the multiplication of cutting speed, feed rate and depth of cut.

To assure that the model formulation is within the feasible range of machining, the following constrains are included in the optimization model:

$$
\begin{gathered}
0.5 \mu \mathrm{m} \leq R_{a} \leq 4 \mu \mathrm{m} \\
600 \mathrm{rpm} \leq x_{1} \leq 2000 \mathrm{rpm} \\
0.02 \mathrm{~mm} / \mathrm{rev} \leq x_{2} \leq 0.12 \mathrm{~mm} / \mathrm{rev} \\
0.2 \mathrm{~mm} \leq x_{3} \leq 1 \mathrm{~mm} \\
0.2 \mathrm{~mm} \leq x_{4} \leq 1.2 \mathrm{~mm}
\end{gathered}
$$

Equation 12 was included in the model because surface roughness values higher than $4 \mu \mathrm{m}$ are not acceptable and those lower than $0.5 \mu \mathrm{m}$ are deemed as not feasible. On the other hand, the ranks established in Equations. 13-16 are set based on the suggestion rates for those cutting conditions in order to guarantee stable machining conditions. The model was implemented in RStudio and the results obtained are presented in the section below.

\section{Results and Discussion}

The results from the ANN showed precise predictions of the surface roughness due to the small MSE obtained for the network structure 4-7-1 with a bias in each layer (0.5042). Also, using the ANN model, it was possible to infer that the equation to predict $R_{a}$ based on the four cutting conditions evaluated is: 


$$
R_{a}=\frac{1}{1+e^{-\left(-4.36-3.62 x_{1}+6.75 x_{2}+2.02 x_{3}+20.73 x_{4}\right)}}
$$

From this equation it is possible to conclude that the parameter with greatest influence on $R_{a}$ is the tool nose radius, followed by the feed rate, the cutting velocity and, finally, depth of cut.

The response surface plotted using Equation 17 are shown in Figure 8. The average surface roughness is plotted as a function of the two most significant design factors, the cutting tool edge radius and the feed rate.

Figure 8A. Surface and contour plots of average surface roughness vs. tool nose radius \& feed rate.

Contour plot of Ra vs. tool nose radius \& feed rate.

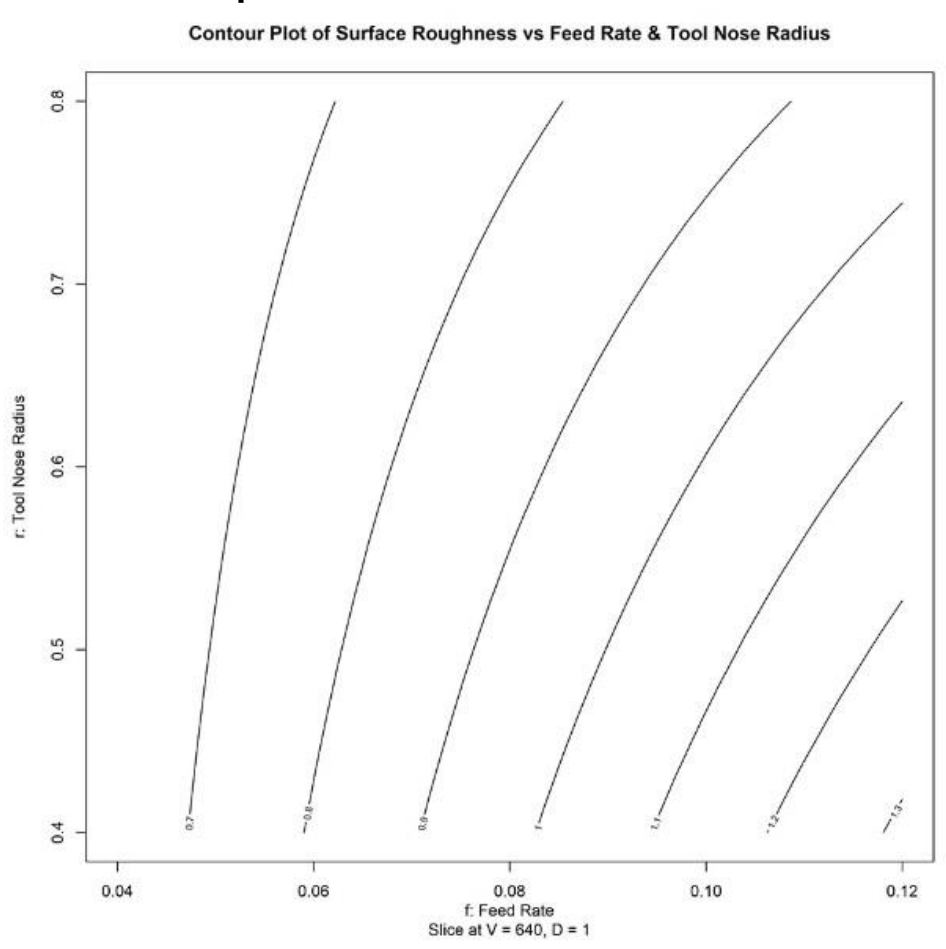

Source: Own work elaboration. 
Figure 8B. Surface plot of Ra vs. tool nose radius \& feed rate.

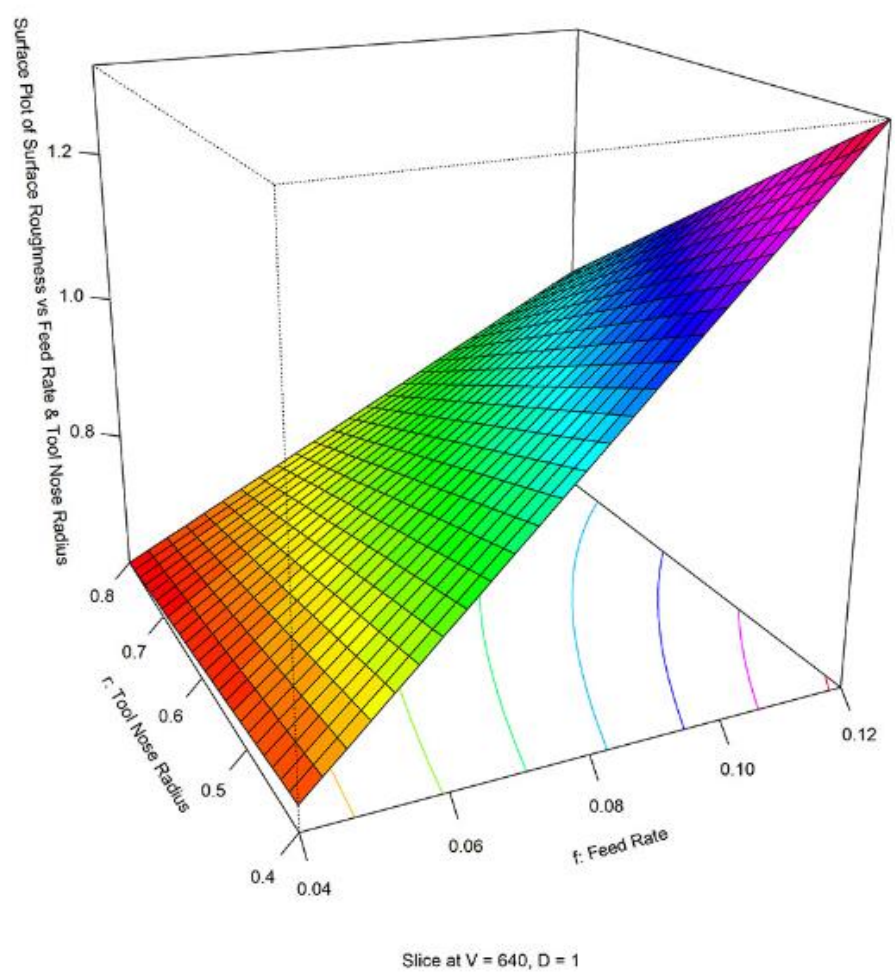

Source: Own work elaboration.

Another way of analyzing the results obtained from the ANN is to plot the experimental values and the predicted values of $R_{a}$. This plot is presented in Figure 9. In this graph, we observe the small difference between actual values (red line) and predicted values (black line) in Figure 10, where the biggest difference between the actual value and the prediction is almost $0.2 \mu \mathrm{m}$.

Figure 9. Comparison of experimental values to predicted values of surface roughness.

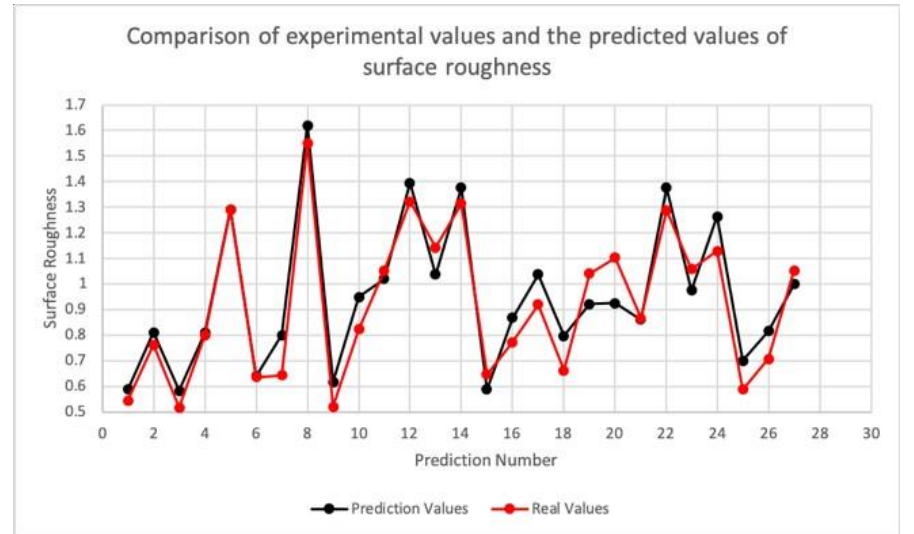

Source: Own work elaboration. 
Figure 10. Graphical representation of errors.



Source: Own work elaboration.

With the results from the ANN using Equation 17, the multi-objective optimization model was implemented in the software RStudio. To develop this model, 100 particles were created, taking into account the restrictions mentioned in the previous section. For each particle, the two objective functions evaluated were calculated as well as the Pareto Front, as shown in Figure 10. As we can see, the results show that the surface roughness $R_{a}$ has a tendency to increase as the $M R R$ is decreasing. This affirmation can be checked with the best values of $R_{a}$ and MRR whose results are listed in Table 5 and Table 6, respectively.

Table 5. Optimal solution when aiming to minimize $\boldsymbol{R}_{\boldsymbol{a}}$.

\begin{tabular}{cccccc}
$\boldsymbol{R}_{\boldsymbol{a}}$ & MRR & $\boldsymbol{v}$ & $\boldsymbol{d}$ & $\boldsymbol{f}$ & $\boldsymbol{r}$ \\
\hline $0.095 \mu \mathrm{m}$ & $1232.77 \mathrm{~mm}^{3} / \mathrm{min}$ & $1995.84 \mathrm{rpm}$ & $0.02 \mathrm{~mm}$ & $0.2 \mathrm{~mm} / \mathrm{rev}$ & $0.3 \mathrm{~mm}$ \\
\hline \multicolumn{5}{c}{ Source: Own work elaboration. } \\
\hline \multicolumn{5}{c}{}
\end{tabular}

Table 6. Optimal solution when aiming to maximize $M R R$.

\begin{tabular}{cccccc}
\hline $\boldsymbol{R}_{\boldsymbol{a}}$ & MRR & $\boldsymbol{v}$ & $\boldsymbol{d}$ & $\boldsymbol{f}$ & $\boldsymbol{r}$ \\
\hline $0.994 \mu \mathrm{m}$ & $38201.6 \mathrm{~mm}^{3} / \mathrm{min}$ & $1995.84 \mathrm{rpm}$ & $0.12 \mathrm{~mm}$ & $1 \mathrm{~mm} / \mathrm{rev}$ & $0.3 \mathrm{~mm}$ \\
\hline
\end{tabular}

\section{Source: Own work elaboration.}

Using the results obtained in the previous tables and the other 98 results from the evaluation of the objective functions with the other particles created, it was possible to find the Pareto Front. It is shown in Figure 11. This Pareto Front indicates that any combination above the curve can be obtained by assigning certain cutting conditions. According to this, any point below the Pareto Front is considered infeasible or, in other words, below the Pareto Front there is no combination of the cutting conditions that can guarantee those $R_{a}$ and $M R R$ values. 
Figure 11. Pareto Front.



Source: Own work elaboration.

Figure 12. Comparison of Pareto Front to Experimental Results.

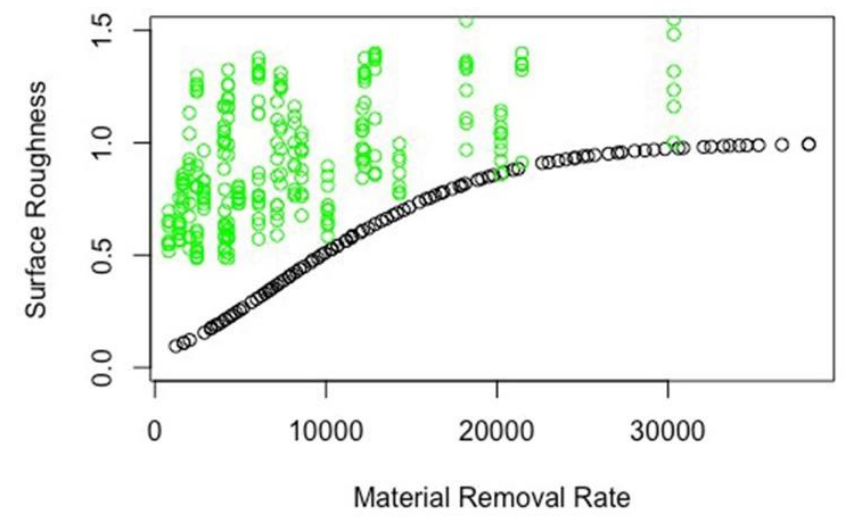

Source: Own work elaboration.

In order to verify the feasibility of the obtained results, the experimental results were overlaid on the Pareto Front plot. As shown in Figure 12, all the values obtained throughout the experiments are above the border, thus confirming the feasibility of the data and the proper construction of the Pareto Front. Finally, to validate the obtained optimal solution from the Pareto Front, we created the two solutions listed in Tables 5 and 6. To do so, we used the cutting conditions as listed in these tables using the cutting tool with $r=0.3 \mathrm{~mm}$ and measured the roughness to compare it to the model results. The results of roughness when aiming for minimum $R_{a}$ resulted in $R_{a}^{\exp }=0.109 \mu \mathrm{m}$, which provides a good match with the model result of $R_{a}=0.095 \mu \mathrm{m}$. Furthermore, we created the sample of optimal conditions where the objective is to obtain maximum $M M R$ while relaxing $R_{a}$. Using the cutting conditions of Table 6 we conducted the experiment and measured the roughness resulting in $R_{a}=1.188 \mu \mathrm{m}$, which is a great match with the theoretical result of $R_{a}=$ $0.994 \mu \mathrm{m}$ as listed in Table 6. It should be noted that in both cases we created the sample to validate the theoretical results through measuring $R_{a}$ since $M M R$ can be obtained using 
the equation. Consequently, we believe that the results of the Pareto Front can be reliably used depending on the desired objective in the industry.

\section{Conclusions}

In a competitive and globalized industry like manufacturing, it is essential to increase productivity and, at the same time, the quality of products. In this paper, a study to predict the optimal cutting conditions for machining processes was conducted. To that end, we made a full factorial experiment design including four factors: cutting speed, depth of cut, feed rate, and tool nose radius. A predictive ANN model was built to calculate the $R_{a}$ values given the proposed cutting conditions, where, to determine the network structure we aimed for the lowest MSE.

Next, we developed a multi-objective optimization model that would allow calculating optimal cutting parameters intended to maximize the $M M R$ and minimize $R_{a}$, resulting in a Pareto Front. The model obtained a front of feasible solutions that is presented in Figure 11. It is concluded that to minimize the $R_{a}$, it is suggested to use $v=1995.84 \mathrm{rpm}, d=$ $0.02 \mathrm{~mm}, f=0.2 \mathrm{~mm} / \mathrm{rev}$ and $r=0.3 \mathrm{~mm}$. On the other hand, to maximize $M R R$, it is suggested to use $v=1995.84 \mathrm{rpm}, d=0.12 \mathrm{~mm}, f=1 \mathrm{~mm} / \mathrm{rev}$ and $r=0.3 \mathrm{~mm}$. These two sample conditions were created experimentally and resulted in good match with the theoretical results of the optimization model. The obtained results indicate that the validated Pareto Front solution presents a viable alternative in identifying optimum machining parameters.

In this context, many works in the literature have been focused on various objectives to be optimized in the machining manufacturing process such as the ones considered in the present paper. However, they have mostly overlooked the effect of the tool edge radius on achieving the desired quality. What differentiates our work form previous efforts is mainly the consideration of the cutting tool nose radius as one of the decision factors of the study in addition to the depth of cut, feed rate, and velocity. Furthermore, combining the ANN with PSO is another added value of this work as compared to the previous studies.

While many studies have focused on building a robust prediction model for machining conditions and many others on optimizing these conditions, there are very few studies that have focused their efforts on developing and/or combining methodologies that propose solutions for before, during, and after the machining process. This work aims to provide such solutions by combining predictive and optimization models, by studying and proposing alternatives for the entire machining process. 


\section{Acknowledgment}

We acknowledge the funding support from Colciencias grant code 120474557650 and the 2019 grant from Faculty of Engineering at Universidad de los Andes, Bogotá, Colombia.

\section{References}

[1] K. Salonitis and P. Ball, "Energy efficient manufacturing from machine tools to manufacturing systems," Procedia CIRP, vol. 7, pp. 634-639, 2013. https://doi.org/10.1016/j.procir.2013.06.045

[2] W. Li, A. Zein, S. Kara and C. Herrmann, "An investigation into fixed energy consumption of machine tools," Globalized Solutions for Sustainability in Manufacturing: Proceedings of the 18th CIRP International Conference on Life Cycle Engineering, pp. 268-273, Springer, Berlin, Heidelberg, 2011.

[3] J. R. Duflou, K. Kellens and W. Dewulf, "Unit process impact assessment for discrete part manufacturing: a state of the art," Journal of Manufacturing Science and Technology, vol. 4, pp. 129-135, 2011. https://doi.org/10.1016/j.cirpj.2011.01.008

[4] G. D'Mello, P. Srinivasa Pai, and R. P. Shetty, "Surface roughness modeling in high speed turning of Ti-6Al-4V - Artificial Neural Network approach," Materials Today: Proceedings, vol. 4, no. 8, pp. 7654-7664, 2017. https://doi.org/10.1016/j.matpr.2017.07.099

[5] R. Kumar and S. Chauhan, "Study on surface roughness measurement for turning of Al 7075/10/SiCp and Al 7075 hybrid composites by using response surface methodology (RSM) and artificial neural networking (ANN)," Measurement, vol. 65, pp. 166-180, 2015. https://doi.org/10.1016/j.measurement.2015.01.003

[6] M. Mia and N. R. Dhar, "Prediction of surface roughness in hard turning under high pressure coolant using Artificial Neural Network," Measurement, vol. 92, pp. 464-474, 2016. https://doi.org/10.1016/j.measurement.2016.06.048

[7] A. C. Basheer, U. A. Dabade, S. S. Joshi, V. V. Bhanuprasad, and V. M. Gadre, "Modeling of surface roughness in precision machining of metal matrix composites using ANN," Journal of Materials Processing Technology, vol. 197, no. 1-3, pp. 439-444, 2008. https://doi.org/10.1016/j.jmatprotec.2007.04.121

[8] B. Anuja Beatrice, E. Kirubakaran, P. Ranjit Jeba Thangaiah, and K. Leo Dev Wins, "Surface roughness prediction using artificial neural network in hard turning of AISI H13 steel with minimal cutting fluid application," Procedia Engineering, vol. 97, pp. 205-211, 2014. https://doi.org/10.1016/j.proeng.2014.12.243

[9] B. C. Abeesh, U. A. Dabade, S. S. Joshi, V. V. Bhanuprasad and V. M. Gadre, "Modeling of surface roughness in precision machining of metal matrix composites using ANN," Journal of Materials Processing Technology, vol. 197, no. 1-3, pp. 439-444, 2008.

[10] T. Erzurumlu and H. Oktem, "Comparison of response surface model with neural network in determining the surface quality of moulded parts," Materials and Design, vol. 28, pp. 459-465, 2007.

[11] J. P. Davim, V. N. Gaitonde and S. R. Karmik, "Investigations into the effect of cutting conditions on surface roughness in turning of free machining steel by ANN models," Journal of Material Processing, vol. 205, pp. 16-23, 2008.

[12] G. Kant and K. S. Sangwan, "Predictive modelling and optimization of machining parameters to minimize surface roughness using artificial neural network coupled with genetic algorithm," Procedia CIRP, vol. 31, pp. 453-458, 2015. 
[13] M. V. Vardhan, G. Sankaraiah, and M. Yohan, "Prediction of surface roughness \& material removal rate for machining of P20 steel in CNC milling using artificial neural networks," Materials Today: Proceedings, vol. 5, no. 9, pp. 18376-18382, 2018. https://doi.org/10.1016/j.matpr.2018.06.177

[14] T. Özel and Y. Karpat, "Predictive modeling of surface roughness and tool wear in hard turning using regression and neural networks," International Journal of Machine Tools and Manufacture, vol. 45, no. 4-5, pp. 467-479, 2005. https://doi.org/10.1016/j.ijmachtools.2004.09.007

[15] G. D’Mello, P. S. Pai, and N. P. Puneet, "Optimization studies in high speed turning of Ti-6Al-4V," Applied Soft Computing, vol. 51, pp. 105-115, 2017. https://doi.org/10.1016/j.asoc.2016.12.003

[16] P. Sivaiah and D. Chakradhar, "Modeling and optimization of sustainable manufacturing process in machining of 17-4 PH stainless steel," Measurement, vol. 134, pp. 142-152, 2019. https://doi.org/10.1016/j.measurement.2018.10.067

[17] M. Nalbant, H. Gokkaya, I. Toktas and G. Sur, "The experimental investigation of the effects of uncoated, PVD and CVD-coated cemented carbide inserts and cutting parameters on surface roughness in CNC turning and its prediction using artificial neural networks," Robotics and Computer-Integrated Manufacturing, vol. 25, pp. 211-223, 2009.

[18] A. M. A. Al-Ahmari, "Predictive machinability models for a selected hard material in turning operations," Journal of Materials Processing Technology, vol. 190, pp. 305-311, 2007.

[19] C. Sanjay and C. Jyothi "A study of surface roughness in drilling using mathematical analysis and neural networks," International Journal of Advanced Manufacturing Technology, vol. 29, pp. 846852, 2006.

[20] S. Dahbi, H. El Moussami, L. Ezzine, D. Samya, and E. L. M. Haj, "Optimization of turning parameters for surface roughness," Xème Conférence Internationale: Conception et Production Intégrées, Tanger, Morocco, 2015. https://hal.archives-ouvertes.fr/hal-01260818/

[21] S. Dahbi, H. El Moussami, and L. Ezzine, "Optimization of turning parameters for surface roughness," International Journal of Modern Engineering Research, vol. 134, pp. 142-152, 2019.

[22] F. Cus and U. Zuperl, "Approach to optimization of cutting conditions by using artificial neural networks," Journal of Materials Processing Technology, vol. 173, pp. 281-290, 2006.

[23] A. Kohli and U. S. Dixit, "A neural-network-based methodology for the prediction of surface roughness in a turning process," International Journal of Advanced Manufacturing Technology, vol. 25, pp. 118-129, 2005.

[24] E. O. Ezugwu, D. A. Fadare, J. Bonneya, R. B. D Silva, and W. F. Sales, "Modelling the correlation between cutting and process parameters in high-speed machining of Inconel 718 alloy using an artificial neural network," International Journal of Machine Tools and Manufacture, vol. 45, pp. 1375-1385, 2005.

[25] W. Grzesick, and S. Brol, "Hybrid approach to surface roughness evaluation in multistage machining processes," Journal of Material Processing Technology, vol. 134, pp. 265-272, 2003.

[26] S. Debnath, M. M. Reddy, and Q. S. Yi, "Influence of cutting fluid conditions and cutting parameters on surface roughness and tool wear in turning process using Taguchi method," Measurement, vol. 78, pp. 111-119, 2016.

[27] G. Kant and K. S. Sangwan, "Prediction and optimization of machining parameters for minimizing power consumption and surface roughness in machining," Journal of Cleaner Production, vol. 83, pp. 151-164, 2014.

[28] H. Aouici, M. A. Yallese, K. Chaoui, T. Mabrouki, and J. F. Rigal, "Analysis of surface roughness and cutting force components in hard turning with CBN tool: Prediction model and cutting conditions optimization," Measurement, vol. 45, no. 3, pp. 344-353, 2012. https://doi.org/10.1016/j.measurement.2011.11.011

[29] U. Zuperl and F. Cus, "Optimization of cutting conditions during cutting by using neural networks," Robotics and Computer-Integrated Manufacturing, vol. 19, pp. 189-199, 2003. 
[30] I. N. Tansel, B. Ozcelik, W. Y. Bao, P. Chen, D. Rincon, and S. Y. Yang, "Selection of optimal cutting conditions by using GONNS," International Journal of Machine Tools and Manufacture, vol. 46, pp. 26-35, 2006.

[31] H. Oktem, T. Erzurumlu, and F. Erzincanli, "Prediction of minimum surface roughness in end milling mold parts using neutral network and genetic algorithm," Journal of Material and Design, vol. 27, pp. 735-744, 2006.

[32] G. Kant and K. S. Sangwan, "Prediction and optimization of machining parameters for minimizing power consumption and surface roughness in machining," Journal of Cleaner Production, vol. 83, pp. 151-164, 2014.

[33] I. Asiltürk and M. Çunkaş, "Modeling and prediction of surface roughness in turning operations using artificial neural network and multiple regression method," Expert Systems with Applications, vol. 38, no. 5, pp. 5826-5832, 2011.

[34] M. V. Vardhan, G. Sankaraiah, and M. Yohan, "Prediction of surface roughness \& material removal rate for machining of $\mathrm{P} 20$ steel in CNC milling using artificial neural networks," Materials Today: Proceedings, vol. 5, no. 9, pp. 18376-18382, 2018.

[35] U. Maheshwera Reddy Paturi, H. Devarasetti, and S. Kumar Reddy Narala, "Application of Regression and Artificial Neural Network Analysis in Modelling of Surface Roughness in Hard Turning of AISI 52100 Steel," Materials Today: Proceedings, vol. 5, no. 2, pp. 4766-4777, 2018.

[36] R. S. Bharathi and N. Baskar, "Optimization techniques for machining operations: A retrospective research based on various mathematical models," International Journal of Advanced Manufacturing Technology, vol. 48, 1075-1090, 2010.

[37] M. Farahnakian, M. R. Razfar, M. Moghri and M. Asadnia, "The selection of milling parameters by the PSO-based neural network modeling method," International Journal of Advanced Manufacturing Technology, vol. 57, pp. 1-12, 2011.

[38] W. Yang, Y. Guo and W. Liao, "Optimization of multi-pass face milling using a fuzzy particle swarm optimization algorithm," International Journal of Advanced Manufacturing Technology, vol. 54, pp. 45-57, 2011.

[39] H. Ganesan, G. Mohankumar, K. Ganesan and K. Ramesh Kumar, "Optimization of machining parameters in turning process using genetic algorithm and particle swarm optimization with experimental verfification," International Journal of Engineering Science and Technology (IJEST), vol. 3, pp. 1091-1102, 2011.

[40] M. R. Razfar, M. Asadnia, M. Haghshenas and M. Farahnakian, "Optimum surface roughness prediction in face milling X20Cr13 using particle swarm optimization algorithm," Proceedings of the Institution of Mechanical Engineers, Part B: Journal of Engineering Manufacture, vol. 224, no. 11, pp. 1645-1653, 2010. https://doi.org/10.1243/09544054JEM1809

[41] L. Y. Zheng and S. G. Ponnambalam, "Optimization of multipass turning operations using particle swarm optimization". Paper presented at the ISMA'10 - 7th International Symposium on Mechatronics and its Applications, pp. 1-6, 2010.

[42] R. V. Rao and P. J. Pawar, "Grinding process parameter optimization using non-traditional optimization algorithms," Proceedings of the Institution of Mechanical Engineers, Part B: Journal of Engineering Manufacture, vol. 224, pp. 887-898, 2010.

[43] R. S. Bharathi and N. Baskar, "Optimization techniques for machining operations: A retrospective research based on various mathematical models," International Journal of Advanced Manufacturing Technology, vol. 48, pp. 1075-1090, 2010.

[44] J. Xi and G. Liao, "Cutting parameter optimization based on particle swarm optimization," Paper presented at the 2009 2nd International Conference on Intelligent Computing Technology and Automation, ICICTA, vol. 1, pp. 255-258, 2009.

[45] I. Escamilla, P. Perez, L. Torres, P. Zambrano and B. Gonzalez, "Optimization using neural network modeling and swarm intelligence in the machining of titanium (ti 6al 4v) alloy," Paper presented at 
the 8th Mexican International Conference on Artificial Intelligence. Proceedings of the Special Session, MICAI, pp. 33-38, 2009.

[46] J. Ciurana, G. Arias and T. Ozel, "Neural network modeling and particle swarm optimization (PSO) of process parameters in pulsed laser micromachining of hardened AISI H13 steel," Materials and Manufacturing Processes, vol. 24, pp. 358-368, 2009.

[47] C. Prakasvudhisarn, S. Kunnapapdeelert and P. Yenradee, "Optimal cutting condition determination for desired surface roughness in end milling," International Journal of Advanced Manufacturing Technology, vol. 41, pp. 440-451, 2009.

[48] J. Srinivas, R. Giri and S. Yang, "Optimization of multi-pass turning using particle swarm intelligence," International Journal of Advanced Manufacturing Technology, vol. 40, pp. 56-66, 2009.

[49] J. G. Li, Y. X. Yao, D. Gao, C. Q. Liu and Z. J. Yuan, "Cutting parameters optimization by using particle swarm optimization (PSO)," Applied Mechanics and Materials, vols. 10-12, pp. 879-883, 2008.

[50] O. Duran, R. Rodriguez and L. A. Consalter, "PSO for selecting cutting tools geometry," Lecture Notes in Computer Science, vol. 5271, pp. 265-272, 2008.

[51] Z. Chen and Y. Li, "An improved particle swarm algorithm and its application in grinding process optimization," Proceedings of the 27th Chinese Control Conference, pp. 2-5, 2008.

[52] H. Zhao, J. G. Li, Y. X. Yao and C. Q. Liu, "Cutting parameters optimization for constant cutting force in milling," Applied Mechanics and Materials, vol. 483, pp. 10-12, 2008.

[53] H. Liu and W. Huang, "Computer numerical control machining parameter optimization based on particle swarm optimization,” J. of Tongji University, vol. 36, pp. 803-806, 2008.

[54] U. Zuperl, F. Cus and V. Gecevska, "Optimization of the characteristic parameters in milling using the PSO evolution technique," Journal of Mechanical Engineering, vol. 6, pp. 354-368, 2007.

[55] H. Huang, A. Li and X. Lin, "Application of PSO-based Wavelet Neural Network in Tool Wear Monitoring," Proceedings of the IEEE International Conference on Automation and Logistics, pp. 2813-2817, 2007.

[56] J. Kennedy and R. C. Eberhart, "Discrete binary version of the particle swarm algorithm," IEEE International Conference on Systems, Man, and Cybernetics. Computational Cybernetics and Simulation, vol. 5, pp. 4104-4108, 1997. https://doi.org/10.1109/ICSMC.1997.637339

[57] J. G. Li, Y. X. Yao, D. Gao, C. Q. Liu, and Z. J. Yuan, "Cutting parameters optimization by using particle swarm optimization (PSO)," Applied Mechanics and Materials, vols. 10-12, pp. 879-883, 2008. https://doi.org/10.4028/www.scientific.net/AMM.10-12.879

[58] N. Yusup, A. M. Zain, and S. Z. M. Hashim, "Overview of PSO for optimizing process parameters of machining," Procedia Engineering, vol. 29, pp. 914-923, 2012. https://doi.org/10.1016/j.proeng.2012.01.064

[59] Y. Karpat and T. Özel, "Multi-objective optimization for turning processes using neural network modeling and dynamic-neighborhood particle swarm optimization," The International Journal of Advanced Manufacturing, vol. 35, no. 3-4, pp. 234-247, 2007.

[60] M. Mia and N. R. Dhar, "Prediction of surface roughness in hard turning under high pressure coolant using Artificial Neural Network," Measurement, vol. 92, pp. 464-474, 2016. https://doi.org/10.1016/j.measurement.2016.06.048

[61] Ş. Karabulut, "Optimization of surface roughness and cutting force during AA7039/A12O3 metal matrix composites milling using neural networks and Taguchi method," Measurement, vol. 66, pp. 139-149, 2015. https://doi.org/10.1016/j.measurement.2015.01.027 


\section{Appendix}

Table A1. Experimental Data.

\begin{tabular}{|c|c|c|c|c|c|}
\hline$\#$ & $\begin{array}{c}\text { Cutting } \\
\text { Speeed } \\
(\mathbf{r p m})\end{array}$ & $\begin{array}{c}\text { Feed } \\
(\mathrm{mm} / \mathrm{rev} .)\end{array}$ & $\begin{array}{c}\text { Depth of cut } \\
(\mathbf{m m})\end{array}$ & $\begin{array}{c}\text { Nose Radius } \\
\quad(\mathbf{m m})\end{array}$ & $\begin{array}{l}\text { Average } \\
\text { Response }\end{array}$ \\
\hline 1 & 640 & 0.04 & 0.2 & 0.8 & 0.5954 \\
\hline 2 & 640 & 0.04 & 0.6 & 0.8 & 0.499 \\
\hline 3 & 640 & 0.04 & 1 & 0.8 & 0.5832 \\
\hline 4 & 640 & 0.08 & 0.2 & 0.8 & 0.772 \\
\hline 5 & 640 & 0.08 & 0.6 & 0.8 & 0.763 \\
\hline 6 & 640 & 0.08 & 1 & 0.8 & 1.044 \\
\hline 7 & 640 & 0.12 & 0.2 & 0.8 & 0.8362 \\
\hline 8 & 640 & 0.12 & 0.6 & 0.8 & 0.957 \\
\hline 9 & 640 & 0.12 & 1 & 0.8 & 1.0676 \\
\hline 10 & 1120 & 0.04 & 0.2 & 0.8 & 0.6482 \\
\hline 11 & 1120 & 0.04 & 0.6 & 0.8 & 0.5512 \\
\hline 12 & 1120 & 0.04 & 1 & 0.8 & 0.7072 \\
\hline 13 & 1120 & 0.08 & 0.2 & 0.8 & 0.8212 \\
\hline 14 & 1120 & 0.08 & 0.6 & 0.8 & 0.7868 \\
\hline 15 & 1120 & 0.08 & 1 & 0.8 & 0.7344 \\
\hline 16 & 1120 & 0.12 & 0.2 & 0.8 & 1.0738 \\
\hline 17 & 1120 & 0.12 & 0.6 & 0.8 & 0.9262 \\
\hline 18 & 1120 & 0.12 & 1 & 0.8 & 0.8502 \\
\hline 19 & 1584 & 0.04 & 0.2 & 0.8 & 0.947 \\
\hline 20 & 1584 & 0.04 & 0.6 & 0.8 & 0.725 \\
\hline 21 & 1584 & 0.04 & 1 & 0.8 & 0.797 \\
\hline 22 & 1584 & 0.08 & 0.2 & 0.8 & 1.035 \\
\hline 23 & 1584 & 0.08 & 0.6 & 0.8 & 1.013 \\
\hline 24 & 1584 & 0.08 & 1 & 0.8 & 1.064 \\
\hline 25 & 1584 & 0.12 & 0.2 & 0.8 & 1.227 \\
\hline 26 & 1584 & 0.12 & 0.6 & 0.8 & 1.188 \\
\hline 27 & 1584 & 0.12 & 1 & 0.8 & 1.117 \\
\hline 28 & 640 & 0.04 & 0.2 & 0.4 & 0.568 \\
\hline 29 & 640 & 0.04 & 0.6 & 0.4 & 0.5672 \\
\hline 30 & 640 & 0.04 & 1 & 0.4 & 0.6362 \\
\hline 31 & 640 & 0.08 & 0.2 & 0.4 & 0.8246 \\
\hline 32 & 640 & 0.08 & 0.6 & 0.4 & 0.764 \\
\hline 33 & 640 & 0.08 & 1 & 0.4 & 0.8466 \\
\hline
\end{tabular}




\begin{tabular}{cccccc}
\hline$\#$ & $\begin{array}{c}\text { Cutting } \\
\text { Speed } \\
(\mathbf{r p m})\end{array}$ & $\begin{array}{c}\text { Feed } \\
(\mathbf{m m} / \mathbf{r e v})\end{array}$ & $\begin{array}{c}\text { Depth of cut } \\
(\mathbf{m m})\end{array}$ & $\begin{array}{c}\text { Nose Radius } \\
(\mathbf{m m})\end{array}$ & $\begin{array}{c}\text { Average } \\
\text { Response }\end{array}$ \\
\hline $\mathbf{3 4}$ & 640 & 0.12 & 0.2 & 0.4 & 1.2548 \\
\hline $\mathbf{3 5}$ & 640 & 0.12 & 0.6 & 0.4 & 1.2668 \\
\hline $\mathbf{3 6}$ & 640 & 0.12 & 1 & 0.4 & 1.2986 \\
\hline $\mathbf{3 7}$ & 1120 & 0.04 & 0.2 & 0.4 & 0.6182 \\
\hline $\mathbf{3 8}$ & 1120 & 0.04 & 0.6 & 0.4 & 0.6312 \\
\hline $\mathbf{3 9}$ & 1120 & 0.04 & 1 & 0.4 & 0.979 \\
\hline $\mathbf{4 0}$ & 1120 & 0.08 & 0.2 & 0.4 & 0.7588 \\
\hline $\mathbf{4 1}$ & 1120 & 0.08 & 0.6 & 0.4 & 0.9932 \\
\hline $\mathbf{4 2}$ & 1120 & 0.08 & 1 & 0.4 & 0.9128 \\
\hline $\mathbf{4 3}$ & 1120 & 0.12 & 0.2 & 0.4 & 1.2468 \\
\hline $\mathbf{4 4}$ & 1120 & 0.12 & 0.6 & 0.4 & 1.3734 \\
\hline $\mathbf{4 5}$ & 1120 & 0.12 & 1 & 0.4 & 1.3542 \\
\hline $\mathbf{4 6}$ & 1584 & 0.04 & 0.2 & 0.4 & 0.6486 \\
\hline $\mathbf{4 7}$ & 1584 & 0.04 & 0.6 & 0.4 & 0.74 \\
\hline $\mathbf{4 8}$ & 1584 & 0.04 & 1 & 0.4 & 0.6436 \\
\hline $\mathbf{4 9}$ & 1584 & 0.08 & 0.2 & 0.4 & 1.0362 \\
\hline $\mathbf{5 0}$ & 1584 & 0.08 & 0.6 & 0.4 & 0.998 \\
\hline $\mathbf{5 1}$ & 1584 & 0.08 & 1 & 0.4 & 0.978 \\
\hline $\mathbf{5 2}$ & 1584 & 0.12 & 0.2 & 0.4 & 1.3122 \\
\hline $\mathbf{5 3}$ & 1584 & 0.12 & 0.6 & 0.4 & 1.4328 \\
\hline $\mathbf{5 4}$ & 1584 & 0.12 & 1 & 0.4 & 1.683 \\
\hline & & & & & \\
\hline
\end{tabular}

Source: Own work elaboration.

${ }^{1}$ See https://rstudio.com/products/rstudio/ 